\title{
Students' Attitudes in Science Learning: Comparison Between Public and Private Junior High Schools
}

\author{
Maison ${ }^{1}$, Kurniawan D. A ${ }^{2}$, Zain M. $\mathrm{S}^{3}$ \\ 1,2,3 Physics Education, Faculty of Education, Universitas Jambi, Jambi, Indonesia
}

\section{A R T I C L E I N F O}

Article history:

Received May 09, 2021

Revised May 10, 2021

Accepted October 24, 2021

Available online November 25, 2021

\section{Kata Kunci :}

Kata kunci: Sikap, Sains, Negeri,

Swasta, SMP

Keywords:

Attitude, Science, Public, Private, Junior High School

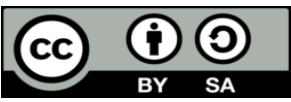

This is an open access article under the $\underline{C C}$ BY-SA license.

Copyright (C) 2021 by Author. Published by Universitas Pendidikan Ganesha

\section{A B S T R A C T}

\begin{abstract}
A $B S T R A K$
Sikap negatif siswa merupakan masalah yang mengganggu proses pembelajaran IPA di sekolah negeri maupun swasta. Sikap negatif siswa dalam belajar IPA merupakan masalah yang kompleks untuk dipecahkan. Sikap negatif yang ditunjukkan adalah siswa tidak patuh ketika diberi tugas dan cenderung tidak suka. Hal ini akan berdampak pada hasil belajar siswa yang rendah. Penelitian ini bertujuan untuk mengevaluasi sikap siswa terhadap mata pelajaran IPA dengan membandingkan sekolah swasta dan negeri. Jenis penelitian yang digunakan adalah metode campuran yang bersifat deskriptif. Instrumen jenis penelitian kuantitatif ini berupa angket, sedangkan instrumen kualitatif berupa lembar wawancara siswa dan guru mata pelajaran IPA. Jumlah sampel kuantitatif sebanyak 236 siswa dengan teknik purposive sampling, sedangkan sampel kualitatif siswa sebanyak delapan siswa dan dua guru IPA. Teknik analisis penelitian kuantitatif yang digunakan adalah statistik deskriptif, dan teknik analisis penelitian kualitatif merangkum hasil wawancara. Hasilnya adalah sikap siswa terhadap mata pelajaran IPA di SMP Negeri dan Swasta sudah baik. Berdasarkan perbandingan sikap siswa, sekolah negeri dikategorikan memiliki sikap yang sedikit lebih baik daripada sekolah swasta. Hasil wawancara dengan siswa dan guru juga dapat disimpulkan bahwa sebagian besar siswa memiliki sikap positif terhadap sains, siswa yang tidak positif ditunjukkan dengan tindakan seperti mengabaikan guru, sibuk sendiri ketika kegiatan pembelajaran berlangsung, mengganggu teman, dll setidaknya ini negatif. sikap harus diubah dalam diri siswa. Hasil perbandingan menunjukkan bahwa siswa SMP negeri memiliki sikap yang sedikit lebih positif dibandingkan siswa swasta.
\end{abstract}

Students' negative attitude is a problem that interferes with the science learning process in public and private schools. Students' negative attitude in learning science is a complex problem to solve. The negative attitude shown is that students are disobedient when given assignments and dislike them. It will have an impact on low student learning outcomes. This study aims to determine students' attitudes towards science subjects by comparing private and public schools. The type of research used is a descriptive mixed method. The instrument of this type of quantitative research is in the form of a questionnaire, while the qualitative instrument is an interview sheet for students and teachers of science subjects. The number of samples was 236 students using the purposive sampling technique, while the qualitative samples were eight students and two science teachers. The quantitative analysis technique used is descriptive statistics, and the qualitative analysis technique summarizes the results of the interviews. The result is that students' attitudes towards science subjects in public and private junior high schools are already promising. Based on student attitudes, public schools are categorized as having slightly better attitudes than private schools. The results of interviews with students and teachers can also be revealed that most students have positive attitudes towards science, students who are not positive with actions such as teachers, are active alone when learning activities take place, disturb friends, etc. are at least harmful. Attitudes must be changed in students. The results show that public junior high school students have slightly more positive attitudes than private students.

\section{INTRODUCTION}

Science is one of the subjects that require students affective to develop well to increase student interest in learning (Astalini, Kurniawan, Melsayanti, et al., 2018; Puspitorini et al., 2014). The science learning process is generally always centered on student cognition without seeing the other side of the mental itself, namely affective (Anwar et al., 2016; Astalini, Kurniawan, \& Putri, 2018). The weakness of learning that rotates on cognitive only is the lack of students' ability to acquire knowledge because the current curriculum 2013 students are required to find their knowledge (Rohita et al., 2018; Subagia \& Wiratma, 2016). In addition, if the knowledge discovery process is good, students will easily understand the concept (Darmaji et al., 2018; Wulandari, 2020). In discovering knowledge through the process, the affective 
side is very involved, namely the attitude towards science. In science learning, teachers generally adhere to conventional learning models so that the teacher cannot directly monitor the affective side of students. Therefore, science learning must have practical activities. Practical activities involve cognitive and psychomotor aspects; if, without the support of students' positive attitudes towards science, learning activities in the classroom will be less effective (Alnajdi, 2018; Mitra et al., 2021; Wright et al., 2018).

The problem that currently occurs is that students have difficulty in learning science. The negative attitude of students in learning science is a complex problem to solve. Students who have a negative attitude will interfere with the learning process (Anwer et al., 2012; Mihladiz et al., 2011). Based on the results of interviews with science teachers at SMPN 17 Jambi City and SMP Xaverius 2 Jambi, it was found that junior high school teachers in public schools and private schools experienced the same problem because students had negative attitudes towards science. The negative attitude shown is that students are disobedient when given an assignment and tend to dislike it. Students are more enthusiastic about certain materials such as biology than physics, and students do not want to learn the basic formulas of physics. In addition, students have difficulty in learning science subjects, are not interested in learning science, and when given group assignments, only some students do. When they don't understand science lessons, students' reactions are lethargic, noisy, ignore classes, and do unnecessary activities. Based on the research, the problems presented also show the fairly same problem (Budiarti et al., 2016; Darmaji et al., 2020; Toma et al., 2019).Based on theoretical evidence, students who have a positive attitude will be responsible and contribute during learning activities (Astalini, Kurniawan, Darmaji, et al., 2019; Şener et al., 2015; Wan Yunus \& Mat Ali, 2018). It is also known that public and private junior high school students have never measured their attitude towards science by their subject teachers. The condition felt by the teacher can be a reference that shows that students' attitudes towards science subjects are not entirely positive. Based on the problems that have been described, it is important to know how students' attitudes towards science in private and public junior high schools, so that the actual situation can be known. This study will focus on knowing the condition of students' attitudes towards science regarding the social implications of science, normality of scientists, adoptions of scientific attitudes, and pleasure in learning science.

According to educational reform, improving student learning in a positive direction is very important (Haghshenas, 2015; Rohita et al., 2018; Syahrial et al., 2019; Webber, 2015).. Educational reform began with a new curriculum in 2013 that adapts to the current state of education, namely the educational environment, and integrates competencies into the cognitive, affective, and psychomotor domains of students (Maharani, 2015; Wahyudi \& Lutfi, 2019). While cognitive skills revolve around the dimensions of knowledge, understanding, and critical thinking about a particular topic, traditional teaching tends to emphasize skills in this area, particularly in low-level goals (Bhuyan \& Khan, 2014; Weng et al., 2019). This traditional thinking indicates that the cognitive realm is solely the ultimate goal of education. Whereas the ultimate goal of education following the bloom taxonomy is to make good students in the cognitive, affective, and psychomotor domains (Arievitch, 2020; Kuboja \& Ngussa, 2015; Sukajaya et al., 2015). For example, in conducting an experiment or practicum, the cognitive domain works when looking for solutions and using concepts, principles, and methods. The psychomotor domain works when following practical procedural steps. After successfully carrying out the practicum, the affective domain works, feelings of pleasure or displeasure with what has been done appear (Sönmez, 2017; Wu et al., 2019). The affective domain is one of the objectives of education. Attitude plays an important role in all aspects of classroom learning.

Teachers are expected to have the competence to be able to change student behavior and knowledge for the better through careful learning planning (Astuti et al., 2021; Wagiran et al., 2019). Because attitudes support the cognitive and psychomotor aspects, it is necessary to measure these attitudes. Students' attitudes towards science subjects, it is needed to evaluate by measuring attitude indicators. The importance of measuring attitudes is to find out how much interest and desire students have to take part in learning activities, especially science subjects. As for what can be measured are two possibilities, namely positive attitudes and negative attitudes, namely a reflection of the attitude of liking or disliking science (Așiksoy \& Islek, 2017; Ma et al., 2020; Memiş \& Kandemir, 2019).If the student's attitude is positive, the student will diligently participate in learning, whereas if the student's attitude is negative, the student is not interested in participating in learning activities (Latipah et al., 2020; Lee \& Kim, 2018; Tekle-Haimanot et al., 2016). But the learning outcomes that students get are relative, even though students have a positive attitude, the level of intelligence determines the learning outcomes students get (Elder et al., 2019; Fernández-Gutiérrez et al., 2020).

The social implication of science is an independent attitude and cooperation in learning activities. The attitude of collaboration provides benefits for students, namely better academic test scores, improved social skills, making students more confident, and a better understanding of the material (Márquez-García et al., 2020; Rabgay, 2018; Rattu, 2017). An independent attitude in planning and implementing the results of investigations help students develop their thinking and communication skills (Demirdağ, 2021; Wildan 
et al., 2019). Science curriculum, school textbooks, teachers, and their teaching practices are important factors that are considered to negatively influence student attitudes towards science and interest in science. An attitude towards investigations in science means a happy or unhappy attitude towards investigating problems in science. Students can take an active part in scientific investigations and problem-solving in inquiry learning models (Moeed, 2013; Swanson et al., 2021). In the process of investigation and problem solving, scientific and thinking skills are used (Setiyani et al., 2020; Suryawati \& Osman, 2018). The adoption of scientific attitudes in this study is the extent to which students apply scientific attitudes in science learning. Pleasure in learning science is a positive attitude towards learning science, determined by the potential of students' science abilities (Shin et al., 2017).Several previous studies examining student attitudes towards science subjects include (Anwer et al., 2012; Maison et al., 2019; Said et al., 2016; Stefan \& Ciomoş, 2010). Based on previous research, no one has examined how students' attitudes toward science compare in public and private junior high schools so that this research will complement prior research on student attitudes towards science in public and private schools. There are four important indicators of student attitudes towards science subjects, including the social implications of science, normality of scientists, attitudes towards investigations in science, adoption of scientific attitudes, pleasure in learning science, interest in increasing the time to study science, and interest in a career in science. These indicators were chosen because they were suitable and in line with students' attitudes towards science subjects. This study aimed to compare the attitudes towards the science of public junior high school and private junior high school students.

\section{METHODS}

This type of research is a combination of quantitative and qualitative (mixed method). Researchers use quantitative methods as the main method, while qualitative methods support quantitative methods (Salim \& Haidir, 2019). The design of this research is a survey. The survey was conducted to answer questions related to the subject's state under study (Gay et al., 2012). The subjects in this study were public and private junior high school students. This research was conducted in public and private schools in the Telanaipura sub-district, Jambi city. The schools that were the research sites were SMPN 17 Jambi City (public schools) and Xaverius 2 Jambi Junior High Schools (private schools). The number of students at the time of sampling was 145 students at state junior high schools and 138 students at private junior high schools. For the samples used to be balanced for comparison, the researchers trimmed the sample quantity by eliminating data that were considered biased or inappropriate. So the sample for the quantitative type is 272 students divided into 136 students from public schools and 136 students from private schools starting from grades VII, VIII, and IX. The number of male students is 67 while female students are 69 for both schools. The sampling technique used was purposive sampling because SMPN 17 Jambi City and SMP Xaverius 2 have facilities and infrastructure that are considered adequate for learning science; besides that, the school's accreditation is good. As for the qualitative type, the sample size is four students per school and one science teacher per school.

The quantitative research analysis technique used is descriptive statistics, and the qualitative research analysis technique summarizes the results of the interviews. Quantitative research was carried out by distributing attitude questionnaires towards science to students via google form, while the qualitative research were interviews with students and science subject teacher using interview sheets. Therefore, four indicators of student attitudes were used, including the social implications of science, normality of scientists, adoption of scientific attitudes, and pleasure in learning science which were adopted from the research with a total of 32 statement items and a Cronbach Alpha of 0.842 for the type quantitative (Astalini \& Kurniawan, 2019). Meanwhile, the qualitative type of interview question grid for students and teachers was developed from the four indicators of student attitudes towards science. The questionnaire for the quantitative type uses a Likert scale with five scales, namely strongly disagree, which means very bad, disagree, which means bad, neutral, which means sufficient, agree, which means good, and strongly agree, which means very good on positive statement items. In contrast, negative statements are the opposite. The lattice of the student attitude questionnaire statement is shown in Table 1. Meanwhile, the division of the intervals based on the indicators is shown in Table 2 .

Table 1. Attitude in Science Learning Questionnaire Statement Grid.

\begin{tabular}{lllc}
\hline \multirow{2}{*}{ Indicators } & \multicolumn{2}{c}{ Num. Items of Statement } & \multirow{2}{*}{ Freq. of Statement } \\
\cline { 2 - 3 } & \multicolumn{1}{c}{$(\mathbf{( + )}$} & \multicolumn{1}{c}{$(\mathbf{)}$} & \\
\hline Social Implications of Science & $1,14,27,39$ & $7,20,32,45,53$ & 9 \\
Normality of Scientist & $8,21,33,46,54$ & 15,40 & 7 \\
\hline
\end{tabular}




\begin{tabular}{ccccc}
\hline \multirow{2}{*}{ Indicators } & \multicolumn{2}{c}{ Num. Items of Statement } & \multirow{2}{*}{ Freq. of Statement } \\
\cline { 2 - 4 } & $\mathbf{( + )}$ & $\mathbf{( - )}$ & 7 \\
\hline Adoptions of Scientific Attitudes & $3,16,28$ & $10,23,35,48$ & 9 \\
Pleasure in Learning Science & $4,17,29$ & $11,24,36,42,49,56$ & 32 \\
\hline \multicolumn{1}{c}{ Total Statement } & 15 & 17 & (Astalini \& Kurniawan, 2019).
\end{tabular}

Table 2. Category and Interval of Attitude in Science Learning indicators

\begin{tabular}{lcc}
\hline \multirow{2}{*}{ Category } & \multicolumn{2}{c}{ Interval of Attitude in Science Learning Indicators } \\
\cline { 2 - 3 } & $\begin{array}{c}\text { Social Implications of Science and } \\
\text { Pleasure in Learning Science }\end{array}$ & $\begin{array}{c}\text { Normality of Scientist and } \\
\text { Adoptions of Scientific Attitudes }\end{array}$ \\
\hline Very Bad & $9.0-16.2$ & $7.0-12.6$ \\
Bad & $16.3-23.4$ & $12.7-18.2$ \\
Enough & $23.5-30.6$ & $18.3-23.8$ \\
Good & $30.7-37.8$ & $23.9-29.4$ \\
Very Good & $37.9-45.0$ & $29.5-35.0$ \\
\hline
\end{tabular}

\section{RESULT AND DISCUSSION}

\section{Results}

The quantitative and qualitative research results were obtained from the analysis carried out on the data collected from the research subjects. The quantitative research results are described in a table 310 per indicator, which is described statistically and separately between private schools and public schools. At the same time, the results of the study were described qualitatively by analyzing students' answers to the questions separately in the table between private schools and public schools. Based on the data processing results that have been carried out, the results obtained are descriptive statistics on the indicators social implications of science in public school and private school. Based on the results of data analysis, that agree holds the highest percentage, namely $60 \%$. The percentage shows that students feel that being independent and cooperating among fellow students in learning is a good thing. In addition, based on the mean, which is 33.4 in the agree ond interval, the median and mode of 33 and 30 are in the agree and neutral intervals. The mode, median, and mean data show that the social implications of science are good. Meanwhile, when compared to gender, female students are better than male students. Based on the results of data analysis, that agree holds the highest percentage, namely $50 \%$. The percentage shows that students feel that being independent and cooperating among fellow students in learning is a good thing. In addition, based on the mean, which is 31.9 in the agreed interval, the median and mode have the same value of 31 which is in the agree interval. The mode, median, and mean data show that the social implications of science are good. Meanwhile, when compared to gender, female students are better than male students.

Based on the results of the data processing that has been carried out, the results obtained are descriptive statistics on the indicators normality of scientists in public school and private school. Based on the results of data analysis, that agree holds the highest percentage, namely $52.2 \%$. The percentage shows that students are as positive about normal scientists as people in general. In addition, based on the mean, 23.8 is in the neutral interval, then the median and mode are 24 and 23, meaning they are in the agree and neutral interval. The mode, median, and mean data showed that the students were neutral but more likely to positively perceive the scientist's normal life as people in general. Meanwhile, when compared to gender, male students performed better than female students. The data shows that the percentage of agreeing to hold the highest percentage is $61 \%$. The percentage shows that students have a positive attitude towards the life of normal scientists like people in general. In addition, based on the mean, median, and mode respectively $24.2,24$, and 24 which are on the agree scale. The mode, median, and mean data show that students have a positive attitude towards the normal life of scientists like people in general. Meanwhile, when compared to gender, male students performed better than female students.

Based on the results of the data processing that has been carried out, the results obtained are descriptive statistics on the indicators Adoptions of Scientific Attitudes in public school and private school. Based on the results of data analysis, that agree holds the highest percentage, namely $41.2 \%$. The percentage shows that adopting a scientific attitude is important for students in learning science. In addition, based on the mean, median, and mode values, respectively, namely $24.1,24$, and 25 , which are on the agree scale show that adopting a scientific attitude is essential for students in learning science. When compared to gender, male students performed better than female students. The neutral holds the highest percentage amount, namely $52.2 \%$. The percentage shows that students are neutral on indicators of adopting a 
scientific attitude in science learning. Besides that, based on the mean, which is 22.7, it is in the neutral interval, then the median and mode of 23 and 24 mean that it is in the neutral interval. Mode, median, and mean data show that students are neutral on the indicators of adopting a scientific attitude in science learning. Meanwhile, when compared to gender, male students performed better than female students. Based on the results of the data processing that has been carried out, the results obtained are descriptive statistics on the indicators of pleasure in learning science in public school and private school. It is known that agree holds the highest percentage, namely $41.9 \%$. The percentage shows that students have a positive attitude towards indicators of pleasure in learning science. In addition, based on the mean, 33.5 on the agree scale, then the median and mode of 34 and 37 on the agree scale. Mode, median, and mean data show that students are happy in learning science. Meanwhile, when compared to gender, female students are better than male students. The data shows that the agree scale holds the highest percentage, namely $52.9 \%$. The percentage shows that students have a positive attitude towards indicators of pleasure in learning science. In addition, based on the mean, 33.5 on the agree scale, then the median and mode of 33 on the agree scale. Mode, median, and mean data show that students are happy in learning science. Meanwhile, when compared to gender, female students are better than male students.

The first interview was conducted with four public school students and four private school students with the following interview questions. Based on interviews with Public School Students and Private School Students, all students answered that working together when learning science was substantial. Question about Do scientists have the same lives as ordinary people; State School Students answered Three students said scientists might live the same lives as regular people, while one person said otherwise. Private School Students answered. All students said scientists may have lived the same lives as ordinary people. Whether it is essential in science learning to adopt a scientific attitude such as solving systematic problems with scientific steps, Public School's Students answered All students answered recurring problem solving with scientific steps is essential. Private School Students answer All students answer systematic problem solving with scientific steps is critical. Questions about Are science lessons fun for you; All students answered science lessons were fun.

Next was interviews with science teachers from private and public schools. What questions do you face regarding your students teaching science; The public school teacher answered that the obstacles I faced were students who were lazy to do assignments and were lazy to follow the science practicum instructions that I explained. The Private School's Teacher stated that some students were disobedient and disliked being given assignments, and students were more enthusiastic about specific subjects such as biology than physics. Questions about what factors cause these difficulties?; The Public School's Teacher stated that the interest or willingness of students to study science was lacking, but not all students were like that. The Private School's Teacher says that this may be due to students' positive attitude towards science before entering junior high school and students' differing talents in individual subjects. Questions about how students behave when they cannot understand the material presented; The Public School's Teacher stated that some students interested in taking science lessons enthusiastically asked their teachers about the material they did not understand. Some students who were not interested tended not to ask questions and do other activities during science learning. Private School's Teacher stated Stupid, noisy in class, annoying friends, not paying attention to lessons, and lazy when studying. Questions about whether many students like science subjects?; The Public School's Teacher stated that most students liked it, especially biology, but in physics, students did not like it because of the difficulty of applying basic mathematics to physics; for example, changing the size of $\mathrm{cm}$ square to mm square is still tricky. The Private School's Teacher stated that most liked science, especially biology, but in physics, students disliked it because of the difficulty of applying basic mathematics to physics; for example, changing the size of square $\mathrm{cm}$ to the mm square is still difficult.

\section{Discussions}

Based on the results that have been obtained, it turns out that public and private school students consider the social implications of science important to be applied in science learning. This social implication is essential when carrying out practicum activities and learning activities in class (Helsa et al., 2021; Prasetyo et al., 2020). To improve independent attitudes and cooperation in learning, jigsaw learning strategies, reading, asking, and answering can be done (Bustami et al., 2017; Marhamah \& Mulyadi, 2013; Yemi et al., 2018). This learning strategy can be used effectively by teachers to stimulate an independent attitude and cooperation during science learning to run well (Nashirotun, 2020; Putra et al., 2018). If a comparison is made, more public school students have a positive attitude from the indicators of the social implications of science. From students' responses to the questionnaire, it's known that the social implications of science are more applied by female students than male students. Students will have a good attitude because they learn and want to listen to explanations from the teacher. It can be seen from the 
responses based on the aspects of independence, namely reading, listening to explanations, and studying at home, which is included in the independent attitude. Based on gender, female students prefer to study independently at home than male students (Shishigu et al., 2018; Tse et al., 2013). In addition, the effect of independent learning, namely reading at home, can indirectly succeed in the school where he studies and study at home, which includes an independent attitude (Haji et al., 2015; Kagan Keskin, 2013; Rahmat et al., 2019). The study results showed that showing that public junior high school students have good social science implications (Maison et al., 2019). However, the results of the study did not compare with private junior high schools. So, public and private junior high school students participating in competitions in the field of science will increase the attitude of social implications of science. The research also shows that rural students already have good social science implications (Anwer et al., 2012; Tanti et al., 2020).

Scientist normality is the student's perception of the activities and life of scientists. Based on the results that have been obtained, it is known that the normality of student scientists, namely their positive attitude towards science, is good for public and private school students. Based on the results in more detail, private students have a better attitude of normality in science than public schools. Based on the past results, students who take part in robotic activities have good scientific normality (Welch, 2010). The most important thing is how to make students understand the normality of these scientists (Bustami et al., 2020; Jamaludin et al., 2020). Previous research which showed that private school students had a good attitude toward scientific normality (Subiantoro, Putra, \& Zain, 2020). Therefore, STEM-based learning must be applied in science learning in schools so that students can build positive perceptions of scientific life (Putri et al., 2020; Rusydiyah et al., 2021). Based on the responses to these scientists, students also need to do science experiments or experiments like scientists. Before that, we must know the origin of why students do not like to do experiments. The reason is that students do not understand how scientists work. The life of scientists is not only in the laboratory and researching; scientists also have a normal life, namely taking care of the family, interacting socially, etc. (Gürgil, 2018). For students, how scientists work is difficult, so that students are reluctant to do science experiments. Therefore, the teacher must be able to explain to students that the life of science researchers is not only in the laboratory and does not interact socially.

When doing scientific work, of course, it is imperative to apply a scientific attitude (Dewi \& Rukmini, 2019; Indiyaningsih et al., 2020; Mutlu, 2020). Therefore, students must have a positive attitude towards scientific attitudes to be willing to adopt scientific attitudes (Hidayati et al., 2019; Rahardja et al., 2019). Based on the research results obtained, public junior high school students have a better attitude towards the adoption of scientific attitudes than private schools. However, junior high school students also need to be taught to apply a scientific attitude, taught through practicum or experimentation, so that the basics of a scientific attitude can be formed from an early age. Then the research states that the fair attitude of teachers is equalizing the assessment, opportunity to participate, treatment, assistance to students to increase the adoption of scientific attitudes in science subjects (Ahad et al., 2021; Robinson \& Fraser, 2013; Weng et al., 2019). By giving fair treatment to students, student attitudes tend to be positive during learning. This must be applied by the teacher so that students and teachers get a positive effect on science learning. The application of science in everyday life helps better understand science. By adopting a scientific attitude, students become more accessible in learning activities and practicum; as a result, learning objectives can be achieved well. Scientific attitudes include being objective towards facts, careful, responsible, openminded, always wanting to observe (Dwianto et al., 2017; Suryawati \& Osman, 2018). Based on student responses from statistical results, namely still hesitant to adopt a scientific attitude, and based on interview responses, students understand that applying science in life will be very helpful. Therefore, teachers must be able to improve students' scientific attitudes.

From the calculated statistical results, it is known that many students have a pleasure in learning science. The results obtained show that private school students are slightly better than public school students. However, the results obtained show that private school students are slightly better than public school students. Based on previous research, if junior high school students have a pleasant attitude in learning good science (Fadilah \& Efendi, 2020; Kurniawan, Astalini, \& Kurniawan, 2019). Based on research, junior high school students from several countries, namely Colombia, America, Estonia, and Sweden, enjoy and are interested in learning science (Ainley \& Ainley, 2011). The pleasure in learning science for junior high school students in Indonesia is quite high (Astalini, Kurniawan, Kurniawan, \& Anggraini, 2019). But the results we got were different from these studies; the reason is that our study coverage was different from that research. Based on the results of interviews with students, it can be concluded that students do not like science subjects. The reason is that many formulas indicate this statement is when students feel bored, what students do is draw and sleep. The comments from students and teachers tend to be different, and the possibility is that the teacher has never measured students' attitudes towards science subjects.

The negative attitude in private and public schools that became the starting point of the research was finally answered. Overall, the attitude of the students turned out to be good. Some students who have 
a negative attitude when various factors may cause learning science. According to the teacher's confession, some of the causes are the lack of students' positive attitudes before entering high school, the lack of ability of students in science, and lack of interest in science. A person's behavior can be influenced by his mood. If a teacher is able to build a pleasant emotional atmosphere for students, the student's attitude will be positive and vice versa (Elen et al., 2013; Petty \& Briñol, 2015). In addition, student attitudes are also influenced and can be built by competition and collaboration in experiments between scientists, teachers, and students (Houseal et al., 2014; Welch, 2010). Using a learning model that invites students to find a science concept (Syahrial et al., 2019). To make it happen, teachers must have good pedagogical abilities (Asrial et al., 2019; Blazar \& Kraft, 2017). Schools must also participate in providing a good learning environment for students and teachers so that the teaching and learning process is maximized (Pahlawati \& Sofyan Zain, 2021; Zain \& Gunawan, 2019; Zain \& Putra, 2020). With better teachers, facilities, and infrastructure in science learning, it is expected that students' attitudes will be more positive. The findings of this study will inform schools that attitudes towards science in private junior high schools are good but not optimal compared to public junior high schools students, so it is necessary to increase the adoption aspect of students' scientific attitudes. Adopting a scientific attitude can be done by inviting students to work together to find concepts in science by conducting experiments (Sukarni et al., 2020). The results of this study can also be a reference for other schools to improve students' attitudes towards science for the better.

\section{CONCLUSION}

The students' attitudes towards learning science at public and private were good because the indicators that were used as references for positive attitudes towards science based on statistical parameters two indicators (social implication of science and adoptions of scientific attitude) are good for public school, and the two indicators (normality of scientist and pleasure in learning science) are good for private school. Meanwhile, the students 'attitudes towards learning science at private junior high schools were categorized as good enough because on the indicators of adopting scientific attitudes, students were still on a neutral scale, so that the students' attitudes were quite positive towards science. Based on the comparison of student attitudes, public schools are categorized as having slightly better attitude than private schools. Interviews with students and teachers can also be concluded that most students have positive attitudes towards science, students who are not positive are shown by actions such as ignoring the teacher, busy alone when learning activities take place, annoy friends, etc. at least this negative attitude must be changed in students.

\section{REFERENCES}

Ahad, R., Mustafa, M. Z., Mohamad, S., Abdullah, N. H. S., \& Nordin, M. N. (2021). Work attitude, organizational commitment and emotional intelligence of Malaysian vocational college teachers. Journal of Technical Education and Training, 13(1), 15-21. https://doi.org/10.30880/jtet.2021.13.01.002.

Ainley, M., \& Ainley, J. (2011). Student engagement with science in early adolescence: The contribution of enjoyment to students' continuing interest in learning about science. Contemporary Educational Psychology, 36(1), 4-12. https://doi.org/10.1016/j.cedpsych.2010.08.001.

Alnajdi, S. M. (2018). The Effectiveness of Designing and Using a Practical Interactive Lesson based on ADDIE Model to Enhance Students' Learning Performances in University of Tabuk. Journal of Education and Learning, 7(6), 212. https://doi.org/10.5539/jel.v7n6p212.

Anwar, H., Jamaluddin, J., \& A.W., J. (2016). Pengembangan Perangkat Pembelajaran IPA Model 5E Di SMP. Jurnal Cakrawala Pendidikan, 1(1), 142-151. https://doi.org/10.21831/cp.v1i1.8385.

Anwer, M., Iqbal, H., \& Harrison, C. (2012). Students' attitude towards science: A case of Pakistan. Pakistan Journal of Social and Clinical Psychology, 9(2), 3-9.

Arievitch, I. M. (2020). The vision of Developmental Teaching and Learning and Bloom's Taxonomy of educational objectives. Learning, Culture and Social Interaction, 25. https://doi.org/10.1016/j.lcsi.2019.01.007.

Aşiksoy, G., \& Islek, D. (2017). The impact of the virtual laboratory on students' attitudes in a general physics laboratory. International Journal of Online Engineering, 13(4), 20-28. https://doi.org/10.3991/ijoe.v13i04.6811.

Asrial, A., Syahrial, S., Kurniawan, D. A., \& Septiasari, R. (2019). Relationship of Pedagogical Competence and Science Competency of Elementary School Teacher Education. PEDAGOGIA: JURNAL PENDIDIKAN, 8(2), 149-157. https://doi.org/0.21070/pedagogia.v8i2.1872. 
Astalini, A., \& Kurniawan, D. A. (2019). Pengembangan Instrumen Sikap Siswa Sekolah Menengah Pertama Terhadap Mata Pelajaran IPA. Jurnal Pendidikan Sains (Jps), 7(1), 1-7. https://doi.org/10.26714/jps.7.1.2019.1-7.

Astalini, A., Kurniawan, D. A., Melsayanti, R., \& Destianti, A. (2018). Sikap Terhadap Mata Pelajaran Ipa Di Smp Se-Kabupaten Muaro Jambi. Lentera Pendidikan : Jurnal Ilmu Tarbiyah Dan Keguruan, 21(2), 214-227. https://doi.org/10.24252/lp.2018v21n2i7.

Astalini, A., Kurniawan, D. A., \& Putri, A. D. (2018). Identifikasi Sikap Implikasi Sosial dari IPA, Ketertarikan Menambah Waktu Belajar IPA, dan Ketertarikan Berkarir Dibidang IPA Siswa SMP Se-Kabupaten Muaro Jambi. Jurnal Tarbiyah: Jurnal Ilmiah Kependidikan, 7(2), 93-108. https://doi.org/10.18592/tarbiyah.v7i2.2142.

Astalini, Kurniawan, D. A., Darmaji, Sholihah, L. R., \& Perdana, R. (2019). Characteristics of students' attitude to Physics in Muaro Jambi High School. Humanities and Social Sciences Reviews, 7(2), 91-99. https://doi.org/10.18510/hssr.2019.7210.

Astalini, Kurniawan, D. A., Kurniawan, N., \& Anggraini, L. (2019). Evaluation of Student's Attitude Toward Science in Indonesia. Open Journal for Educational Research, 3(1), 1-12. https://doi.org/10.32591/coas.ojer.0302.01039h.

Astuti, M., Arifin, Z., Mutohhari, F., \& Nurtanto, M. (2021). Competency of Digital Technology: The Maturity Levels of Teachers and Students in Vocational Education in Indonesia. Journal of Education Technology, 5(2), 254-262. https://doi.org/10.23887/jet.v5i3.35108.

Bhuyan, M. H., \& Khan, S. S. A. (2014). Teaching a numerical analysis course for electrical engineering students in the cognitive domain. International Journal of Electrical Engineering and Education, 51(1), 82-92. https://doi.org/10.7227/IJEEE.51.1.7.

Blazar, D., \& Kraft, M. A. (2017). Teacher and Teaching Effects on Students' Attitudes and Behaviors. Educational Evaluation and Policy Analysis, 39(1), 146-170. https://doi.org/10.3102/0162373716670260.

Budiarti, R., Wilujeng, I., Jumadi, J., \& Senam, S. (2016). Pengaruh Pembelajaran IPA Berbasis Sets Terhadap Pengetahuan Lintas Disiplin Peserta Didik. Jurnal Cakrawala Pendidikan, 3(3). https://doi.org/10.21831/Cp.V35i3.10419.

Bustami, Ngadimin, \& Farhan, A. (2020). The Difficulty Factors of Students to Understand Mathematics Physics 1 at Physics Education Department FKIP Unsyiah. Asian Journal of Science Education, 2(1), 1-10. https://doi.org/10.24815/ajse.v2i1.14725.

Bustami, Y., Corebima, A. D., Suarsini, E., \& Ibrohim. (2017). The social attitude empowerment of biology students: Implementation JiRQA learning strategy in different ethnics. International Journal of Instruction, 10(3), 15-30. https://doi.org/10.12973/iji.2017.1032a.

Darmaji, Astalini, Kurniawan, D. A., Sari, N., Wiza, O. H., \& Putri, Y. E. (2020). Investigation of students' psychology: The relationship among students' attitudes, persistence, creativity, and tolerance toward natural science subjects. Universal Journal of Educational Research, 8(4), 1155-1166. https://doi.org/10.13189/ujer.2020.080405.

Darmaji, D., Kurniawan, D. A., Suryani, A., \& Lestari, A. (2018). An Identification of Physics Pre-Service Teachers' Science Process Skills Through Science Process Skills-Based Practicum Guidebook. Jurnal $\begin{array}{llll}\text { Ilmiah Pendidikan Fisika Al-Biruni, } & 7(2),\end{array}$ https://doi.org/10.24042/jipfalbiruni.v7i2.2690.

Demirdağ, S. (2021). Communication Skills and Time Management as the Predictors of Student Motivation. International Journal of Psychology and Educational Studies, 8(1), 38-50. https://doi.org/10.17220/ijpes.2021.8.1.222.

Dewi, R. A. K., \& Rukmini, P. (2019). The effect of thematic learning by using a scientific approach to increase the multiple intelligence of students. Jurnal Prima Edukasia, 7(1), 40-46. https://doi.org/10.21831/jpe.v7i1.24326.

Dwianto, A., Wilujeng, I., Prasetyo, Z. K., \& Suryadarma, I. G. P. (2017). The development of science domain based learning tool which is integrated with local wisdom to improve science process skill and scientific attitude. Jurnal Pendidikan IPA Indonesia, 6(1), 23-31. https://doi.org/10.15294/jpii.v6i1.7205.

Elder, J. J., Franco, K. A., Gulley, S. L., Hughes, C. T., \& Infanti, L. M. (2019). Implementation of Required Electronic Learning Modules to Enhance Nursing Pharmacotherapy Knowledge of Select Hematopoietic Stem Cell Transplant Topics. Biology of Blood and Marrow Transplantation, 25(3), S303. https://doi.org/10.1016/j.bbmt.2018.12.655.

Elen, M., D'Heer, E., Geuens, M., \& Vermeir, I. (2013). The influence of mood on attitude-behavior consistency. Journal of Business Research, 66(7), 917-923. https://doi.org/10.1016/j.jbusres.2011.12.011. 
Fadilah, N., \& Efendi, N. (2020). Student Pleasure Attitude and Interest in Spending Time Learning Science Against Student Cognitive Learning Outcomes. Academia Open, 3, 1-11. https://doi.org/10.21070/acopen.3.2020.497.

Fernández-Gutiérrez, M., Gimenez, G., \& Calero, J. (2020). Is the use of ICT in education leading to higher student outcomes? Analysis from the Spanish Autonomous Communities. Computers and Education, 157, 103969. https://doi.org/10.1016/j.compedu.2020.103969.

Gay, L. R., Mills, G. E., \& Airasian, P. W. (2012). Educational Research Competencies for Analysis and Applications (10th ed.). Pearson Education, Inc.

Gürgil, F. (2018). A Study on Social Studies Teacher Candidates' Perception of Science, Scientific Research and Scientists. International Journal of Progressive Education, 14(3), 141-160. https: //doi.org/10.29329/ijpe.2018.146.10.

Haghshenas, Z. (2015). Case Studies in Three Domains of Learning: Cognitive, Affective, Psychomotor. International Journal of Psychological and Behavioral Sciences, 9(6), 2104-2107. https: //doi.org/https: //doi.org/10.5281/zenodo.1108120.

Haji, A. G., Safriana, \& Safitri, R. (2015). The use of problem based learning to increase students' learning independent and to investigate students' concept understanding on rotational dynamic at students of SMA Negeri 4 Banda Aceh. Jurnal Pendidikan IPA Indonesia, 4(1), 67-72. https://doi.org/10.15294/jpii.v4i1.3503.

Helsa, Y., Ariani, Y., \& Kenedi, A. (2021). Digital Class Model in Mathematics Learning in Elementary School Using Social Learning Network Schoology. Atlantis Press, 382(Icet 2019), 2016-2019. https://doi.org/10.4108/eai.4-11-2020.2304599.

Hidayati, S. K., Perizade, B., \& Widiyanti, M. (2019). Effect Of Work Discipline And Work Environment To Performance Of Employees. International Journal of Scientific and Research Publications (IJSRP), 9(12). https://doi.org/10.29322/ijsrp.9.12.2019.p9643.

Houseal, A. K., Abd-El-Khalick, F., \& Destefano, L. (2014). Impact of a student-teacher-scientist partnership on students' and teachers' content knowledge, attitudes toward science, and pedagogical practices. Journal of Research in Science Teaching, 51(1), 84-115. https://doi.org/10.1002/tea.21126.

Indiyaningsih, K. M. H., Murdyastuti, A., \& Puspitaningtyas, Z. (2020). Efeect of human resource competency, work culture and utilization of information technology to performance of employees. International Journal of Scientific and Technology Research, 9(4), 3636-3641. https://doi.org/10.19184/issrd.v2i1.17468.

Jamaludin, G. M., Supriatna, D., \& Burhani, A. Z. (2020). the Effect of Online Learning System During the Covid-19 Pandemic on Students' Learning Motivation and Interest in Learning. Jurnal Tatsqif, 18(2), 169-182. https://doi.org/10.20414/jtq.v18i2.2795.

Kagan Keskin, H. (2013). Impacts of reading metacognitive strategies and reading attitudes on school success. International Journal of Academic Research, 5(5), 312-317. https://doi.org/10.7813/20754124.2013/5-5/b.48.

Kuboja, J. M., \& Ngussa, B. M. (2015). Affective Learning and Cognitive Skills Improvement: Experience of Selected Schools in Arusha, Tanzania. International Journal of Academic Research in Progressive Education and Development, 4(2), 38-53. https://doi.org/10.6007/ijarped/v4-i2/1727.

Kurniawan, D. A., Astalini, A., \& Kurniawan, N. (2019). Analisis Sikap Siswa Smp Terhadap Mata Pelajaran Ipa. Lentera Pendidikan: Jurnal Ilmu Tarbiyah Dan Keguruan, 22(2), 323. https://doi.org/10.24252/lp.2019v22n2i14.

Latipah, E., Kistoro, H. C. A., \& Khairunnisa, I. (2020). Scientific Attitudes in Islamic Education Learning: Relationship and the Role of Self-Efficacy and Social Support. Edukasia: Jurnal Penelitian Pendidikan Islam. https://doi.org/10.21043/edukasia.v15i1.7364.

Lee, S., \& Kim, S. H. (2018). Scientific Knowledge and Attitudes Toward Science in South Korea: Does Knowledge Lead to Favorable Attitudes? Science Communication, 40(2), 147-172. https://doi.org/10.1177/1075547017753189.

Ma, H. Y., Kao, J. C., Kao, R. H., \& Cho, C. C. (2020). How to shape the employees' sustainable work attitude: The moderating effect of supervisor attitudes. Sustainability (Switzerland), 12(20), 1-27. https://doi.org/10.3390/su12208331.

Maharani, Y. S. (2015). Efektivitas Multimedia Pembelajaran Interaktif Berbasis Kurikulum 2013. Indonesian Journal of Curriculum and Educational Technology Studies, 3(1), 31-40. https://doi.org/10.15294/ijcets.v3i1.8683.

Maison, Ernawati, M. D. W., Budiarti, R. S., Kurniawan, W., Ningsih, Y., Puspitasari, T. O., Jannah, N., \& Putra, D. S. (2019). Learning in nature science: social implications, normality of scientist, attitudes towards investigation of natural science, and interest adds to science learning time. International Journal of Scientific and Technology Research, 8(12), 1478-1484. 
Marhamah, M., \& Mulyadi, M. (2013). Jigsaw Cooperative Learning: A Viable Teaching-Learning Strategy? Journal of Educational and Social Research, 3(7), 710-715. https://doi.org/10.5901/jesr.2013.v3n7p710.

Márquez-García, M. J., Kirsch, W., \& Leite-Mendez, A. (2020). Learning and collaboration in pre-service teacher education: Narrative analysis in a service-learning experience at Andalusian public schools. Teaching and Teacher Education, 96. https://doi.org/10.1016/j.tate.2020.103187.

Memiş, A. D., \& Kandemir, H. (2019). The Relationship Between the Study Habits and Attitudes and Metacognitive Reading Comprehension Self-Awareness, Reading Comprehension, Reading Attitudes. World Journal of Education, 9(4), 133. https: //doi.org/10.5430/wje.v9n4p133.

Mihladiz, G., Duran, M., \& Doğan, A. (2011). Examining primary school students' attitudes towards science in terms of gender, class level and income level. Procedia - Social and Behavioral Sciences, 15, 25822588. https://doi.org/10.1016/j.sbspro.2011.04.150.

Mitra, N. K., Aung, H. H., Kumari, M., Perera, J., Sivakumar, A., Singh, A., \& Nadarajah, V. D. (2021). Improving the learning process in anatomy practical sessions of chiropractic program using e-learning tool. Translational Research in Anatomy, 23, 100100. https://doi.org/10.1016/j.tria.2020.100100.

Moeed, A. (2013). Science investigation that best supports student learning: Teachers understanding of science investigation. International Journal of Environmental and Science Education, 8(4), 537-559. https://doi.org/10.12973/ijese.2013.218a.

Mutlu, A. (2020). Evaluation of students' scientific process skills through reflective worksheets in the inquiry-based learning environments. Reflective Practice, 21(2). https: //doi.org/10.1080/14623943.2020.1736999.

Nashirotun, B. (2020). Peningkatan Aktivitas dan Hasil Belajar Siswa dengan Metode Jigsaw dan Media Tubuh Manusia pada Pembelajaran IPA di MTs. Negeri 4 Klaten Jawa Tengah. Jurnal Paedagogy, 7(4), 402. https://doi.org/10.33394/jp.v7i4.2945.

Pahlawati, Y., \& Sofyan Zain, M. (2021). Korelasi Lingkungan Belajar Terhadap Sikap Pada Mata Pelajaran Fisika. Integrated Science Education Journal, 2(1), 1-6. https://doi.org/10.37251/isej.v2i1.129.

Petty, R. E., \& Briñol, P. (2015). Emotion and persuasion: Cognitive and meta-cognitive processes impact attitudes. Cognition and Emotion, 29(1), 1-26. https://doi.org/10.1080/02699931.2014.967183.

Prasetyo, G., Hidayatullah, M. F., Akhyar, M., Wiranto, \& Perdana, R. (2020). Strengthening Students' Character Through Multimedia Learning In Primary Schools Education: Systematic LiteraturPrasetyo, G., Hidayatullah, M. F., Akhyar, M., Wiranto, \& Perdana, R. (2020). Strengthening Students' Character Through Multimedia Learning In . Humanities \& Social Sciences Reviews, 8(3), 268-277. https://doi.org/10.18510/hssr.2020.8328.

Puspitorini, Subali, \& Jumadi. (2014). Penggunaan Media Komik Dalam Pembelajaran Ipa Untuk Meningkatkan Motivasi Dan Hasil Belajar Kognitif Dan Afektif. Cakrawala Pendidikan, 33(3), 413420. https://doi.org/10.21831/cp.v3i3.2385.

Putra, I. B. P. A., Pujani, N. M., \& Juniartina, P. P. (2018). Pengaruh Model Pembelajaran Kooperatif Tipe Jigsaw Terhadap Pemahaman Konsep Ipa Siswa. Jurnal Pendidikan Dan Pembelajaran Sains Indonesia (JPPSI), 1(2), 80. https://doi.org/10.23887/jppsi.v1i2.17215.

Putri, C. D., Pursitasari, I. D., \& Rubini, B. (2020). Problem Based Learning Terintegrasi STEM Di Era Pandemi Covid-19 Untuk Meningkatkan Keterampilan Berpikir Kritis Siswa. JIPI (Jurnal IPA \& Pembelajaran IPA), 4(2), 193-204. https://doi.org/10.24815/jipi.v4i2.17859.

Rabgay, T. (2018). The effect of using cooperative learning method on tenth grade students' learning achievement and attitude towards biology. International Journal of Instruction, 11(2), 265-280. https://doi.org/10.12973/iji.2018.11218a.

Rahardja, U., Lutfiani, N., \& Amelia, S. (2019). Creative Content Marketing In Scientific Publication Management In Industrial Era 4.0. Aptisi Transactions on Management (ATM), 3(2), 168-178. https://doi.org/10.33050/atm.v3i2.991.

Rahmat, R. F., Mursyida, L., Rizal, F., Krismadinata, K., \& Yunus, Y. (2019). Pengembangan media pembelajaran berbasis mobile learning pada mata pelajaran simulasi digital. Jurnal Inovasi Teknologi Pendidikan, 6(2), 116-126. https://doi.org/10.21831/jitp.v6i2.27414.

Rattu, J. A. (2017). Penilaian Kompetensi Sikap Pada Mahasiswa Jurusan Ppkn Fis Unima. Jurnal Civic Education: Media Kajian Pancasila Dan Kewarganegaraan, 1(1), 9. https://doi.org/10.36412/ce.v1i1.490.

Robinson, E., \& Fraser, B. J. (2013). Kindergarten students' and parents' perceptions of science classroom environments: Achievement and attitudes. Learning Environments Research, 16(2), 151-167. https://doi.org/10.1007/s10984-013-9138-6. 
Rohita, R., Fitria, N., Bustan, R., \& Haryadi, D. (2018). Teacher's Understanding of the Scientific Approach in the 2013 Curriculum for Early Childhood Education. Jurnal Obsesi : Jurnal Pendidikan Anak Usia Dini, 2(2), 235. https://doi.org/10.31004/obsesi.v2i2.105.

Rusydiyah, E. F., Indrawati, D., Jazil, S., Susilawati, \& Gusniwati. (2021). Stem learning environment: Perceptions and implementation skills in prospective science teachers. Jurnal Pendidikan IPA Indonesia, 10(1), 138-148. https://doi.org/10.15294/jpii.v10i1.28303.

Said, Z., Summers, R., Abd-el-khalick, F., \& Wang, S. (2016). Attitudes toward science among grades 3 through 12 Arab students in Qatar : findings from a cross- sectional national study. International Journal of Science Education, 0693(March). https://doi.org/10.1080/09500693.2016.1156184.

Salim, \& Haidir. (2019). Penelitian Pendidikan Metode, Pendekatan, dan Jenis. Kencana.

Şener, N., Türk, C., \& Taş, E. (2015). Improving Science Attitude and Creative Thinking through Science Education Project: A Design, Implementation and Assessment. Journal of Education and Training Studies, 3(4), 57-67. https://doi.org/10.11114/jets.v3i4.771.

Setiyani, S., Fitriyani, N., \& Sagita, L. (2020). Improving student's mathematical problem solving skills through Quizizz. JRAMathEdu (Journal of Research and Advances in Mathematics Education), 5(3), 276-288. https://doi.org/10.23917/jramathedu.v5i3.10696.

Shin, S., Lee, J. K., \& Ha, M. (2017). Influence of career motivation on science learning in Korean high-school students. Eurasia Journal of Mathematics, Science and Technology Education, 13(5), 1517-1538. https://doi.org/10.12973/eurasia.2017.00683a.

Shishigu, A., Hailu, A., \& Anibo, Z. (2018). Problem-based learning and conceptual understanding of college female students in physics. Eurasia Journal of Mathematics, Science and Technology Education, 14(1), 145-154. https://doi.org/10.12973/ejmste/78035.

Sönmez, V. (2017). Association of Cognitive , Affective , Psychomotor and Intuitive Domains in Education , Sönmez Model. Universal Journal of Educational Research, 5(3), 347-356. https://doi.org/10.13189/ujer.2017.050307.

Stefan, M., \& Ciomoș, F. (2010). The 8th and 9th Grades Students' Attitude Towards Teaching and Learning Physics. Acta Didactica Napocensia, 3(3), 7-14.

Subagia, I. W., \& Wiratma, I. G. L. (2016). Profil Penilaian Hasil Belajar Siswa Berdasarkan Kurikulum 2013. JPI (Jurnal Pendidikan Indonesia), 5(1), 39-54. https://doi.org/10.23887/jpi-undiksha.v5i1.8293.

Subiantoro, C., Putra, D. S., \& Zain, M. S. (2020). Identifikasi Sikap: Ketertarikan Meluangkan Waktu Belajar Fisika, Normalitas Ilmuwan, Adopsi Sikap Ilmiah (Attitude Identification: Interest in Spending Time Studying Physics, Scientist Normality, Adoption of Scientific Attitudes). SEJ (Science Education Journal), 3(2), 93. https://doi.org/10.21070/sej.v3i2.2701.

Sukajaya, I., Eddy Purnama, I., \& Purnomo, M. H. (2015). Intelligent classification of learner's cognitive domain using bayes net, naïve bayes, and j48 utilizing bloom's taxonomy-based serious game. International Journal of Emerging Technologies in Learning, 10(2), 46-52. https://doi.org/10.3991/ijet.v10i1.4451.

Sukarni, W., Jannah, N., Qoriyana, D., \& Zain, M. S. (2020). Scientific Attitude Identification and Interest of Pursuing Career in The Physics. Tarbiyah: Jurnal Ilmiah Kependidikan, 9(1), 66-77. https://doi.org/http://dx.doi.org/10.18592/tarbiyah.v9i1.3297.

Suryawati, E., \& Osman, K. (2018). Contextual learning: Innovative approach towards the development of students' scientific attitude and natural science performance. Eurasia Journal of Mathematics, Science and Technology Education, 14(1), 61-76. https://doi.org/10.12973/ejmste/79329.

Swanson, H. L., Arizmendi, G. D., \& Li, J.-T. (2021). Working memory growth predicts mathematical problemsolving growth among emergent bilingual children. Journal of Experimental Child Psychology, 201. https://doi.org/10.1016/j.jecp.2020.104988.

Syahrial, S., Asrial, A., Kurniawan, D. A., Nugroho, P., Septiasari, R., Pratama, R. A., \& Perdana, R. (2019). Increased Behavior of Students' Attitudes to Cultural Values Using the Inquiry Learning Model Assisted by Ethnoconstructivism. Journal of Educational Science and Technology (EST), 5(2), 166175. https://doi.org/10.26858/est.v5i2.9670.

Tanti, T., Kurniawan, D. A., Perdana, R., \& Wiza, O. H. (2020). Comparison of Student Attitudes Toward Natural Sciences in Rural Middle Schools in Jambi Province. Ta'dib, 23(1), 63. https://doi.org/10.31958/jt.v23i1.1607.

Tekle-Haimanot, R., Pierre-Marie, P., Daniel, G., Worku, D. K., Belay, H. D., \& Gebrewold, M. A. (2016). Impact of An Educational Comic Book on Epilepsy-Related Knowledge, Awareness, and Attitudes Among School Children in Ethiopia. Epilepsy and Behavior, 61, 218-223. https://doi.org/10.1016/j.yebeh.2016.05.002.

Toma, R. B., Greca, I. M., \& Orozco Gómez, M. L. (2019). Attitudes towards science and views of nature of science among elementary school sToma, R. B., Greca, I. M., \& Orozco Gómez, M. L. (2019). Attitudes 
towards science and views of nature of science among elementary school students in terms of gender, cultur. Research in Science and Technological Education, 37(4), 492-515. https://doi.org/10.1080/02635143.2018.1561433.

Tse, S. K., Xiao, X., \& Lam, W. (2013). The influences of gender, reading ability, independent reading, and context on reading attitude. Written Language \& Literacy, 16(2), 241-271. https://doi.org/10.1075/wll.16.2.05tse.

Wagiran, Pardjono, Suyanto, W., Sofyan, H., Soenarto, S., \& Yudantoko, A. (2019). Competencies of Future Vocational Teachers: Perspective of in-Service Teachers and Educational Experts. Cakrawala Pendidikan, 38(2), 388-400. https://doi.org/10.21831/cp.v38i2.25393.

Wahyudi, M. A., \& Lutfi, A. (2019). Analisis Reformasi Pendidikan dalam Mewujudkan Pemerataan Kualitas Pendidikan di Indonesia. Jurnal Administrasi Publik, 9(2), 191-201. https://doi.org/10.31289/jap.v9i2.2921.

Wan Yunus, F., \& Mat Ali, Z. (2018). Attitude towards Learning Chemistry among Secondary School Students in Malaysia. Asian Journal of Behavioural Studies, 3(9), 63. https://doi.org/10.21834/ajbes.v3i9.61.

Webber, J. (2015). Character, attitude and disposition. European Journal of Philosophy, 23(4), 1082-1096. https://doi.org/10.1111/ejop.12028.

Welch, A. G. (2010). Using the TOSRA to assess high school students' attitudes toward science after competing in the first robotics competition: An exploratory study. Eurasia Journal of Mathematics, Science and Technology Education, 6(3), 187-197. https://doi.org/10.12973/ejmste/75239.

Weng, F., Ho, H. J., Yang, R. J., \& Weng, C. H. (2019). The influence of learning style on learning attitude with multimedia teaching materials. Eurasia Journal of Mathematics, Science and Technology Education, 15(1), 1-9. https://doi.org/10.29333/ejmste/100389.

Wildan, W., Hakim, A., Siahaan, J., \& Anwar, Y. A. S. (2019). A stepwise inquiry approach to improving communication skills and scientific attitudes on a biochemistry course. International Journal of Instruction, 12(4), 407-422. https://doi.org/10.29333/iji.2019.12427a.

Wright, J. S., Read, D., Hughes, O., \& Hyde, J. (2018). Tracking and assessing practical chemistry skills development: practical skills portfolios. New Directions in the Teaching of Physical Sciences, 13(1). https://doi.org/10.29311/ndtps.v0i13.2905.

Wu, W. H., Kao, H. Y., Wu, S. H., \& Wei, C. W. (2019). Development and evaluation of affective domain using student's feedback in entrepreneurial Massive Open Online Courses. Frontiers in Psychology, 10(MAY). https://doi.org/10.3389/fpsyg.2019.01109.

Wulandari, I. G. A. A. (2020). Implementation of the 2013 Curriculum Based on a Scientific Approach (Case Study at SD Cluster II Kintamani). International Journal of Elementary Education, 4(3), 422-430. https://doi.org/10.23887/ijee.v4i3.28172.

Yemi, T. M., Binti, N., \& Azid, H. (2018). Effect Of Jigsaw Strategy Of Cooperative Learning On Mathematics Achievement Among Secondary School Students. European Journal of Education Studies, 51-61. https://doi.org/10.5281/zenodo.1167888.

Zain, M. S., \& Gunawan, G. (2019). Karakter Peduli Lingkungan Terhadap Pembelajaran Fisika. MAGISTRA: Jurnal Keguruan Dan Ilmu Pendidikan, 6(2), 90-100. https://doi.org/10.35724/magistra.v6i2.1429

Zain, M. S., \& Putra, D. S. (2020). Analisis Lingkungan Belajar: Metode Mengajar, Kurikulum Fisika, Relasi Guru Dengan Siswa, dan Disiplin Sekolah. Jurnal Pendidikan Fisika, 8(1), 30-41. https://doi.org/10.24252/jpf.v8i1.12071. 